\title{
Spirituality in Education
}

\section{Introduction}

In this article the concept of spirituality in the educational framework is discussed. The concepts of religion and spirituality are compared. The psychological view of spirituality is presented with a new suggested intelligence type: spiritual intelligence. The educational view emphasizes spiritual sensitivity as a universal human ability that needs to be developed through education. The sociological view of spirituality explores it as an expression of postsecular religiosity. Empirical studies indicate that an increasing number of people now prefer to call themselves 'spiritual' rather than 'religious' (Heelas \& Woodhead 2005; Mikkola, Niemelä \& Petterson 2007). This trend seems to be more present in some European countries, for example, in the Netherlands, the United Kingdom and Finland. Empirical studies on spirituality are reviewed and discussed. A special emphasis is given to the Finnish research findings related to the spirituality of a new generation or young adults. It is argued that understanding spirituality as an expression of postsecular religiosity gives more room for young adults to participate in communicative action concerning religion. This would promote a discursive religiousness in the spirit of Jürgen Habermas, in which a plurality of religious beliefs and practices are acknowledged and a dialogical and inter-religious approach is advocated.

\section{Different definitions of spirituality}

\section{Religion and spirituality}

The meanings given to the concepts of religion and spirituality have evolved over the centuries. William James (2003 (1902): 32) defined religion as 'the feelings, acts and experiences of individual men in their solitude. Since the time of James, few psychologists have taken a serious look at religious institutions and the roles they play in shaping character. Today some writers use the terms 'religion' and 'spirituality' interchangeably to add linguistic 
variety to their terminology. However, many researchers define spirituality in contrast to religion. In these definitions, religion is usually defined as the organizational, the ritual, and the ideological. The spiritual then refers to the personal, the affective, the experiential, and the thoughtful. The reminder that an individual can be spiritual without being religious or religious without being spiritual, has become a standard theme of many papers on spirituality (Pargament 1999). It seems clear that spirituality must be seen as a wider concept than religion. This kind of understanding of these concepts indicates that religion and spirituality share some common areas but that they also have their own areas of interest (Stifoss-Hanssen 1999).

\section{Spiritual intelligence}

The psychological view on spirituality studies it in the framework of multiple intelligences (Gardner 1983). The most recently suggested intelligence types include emotional and spiritual intelligence. Daniel Goleman (1995) has suggested that emotional intelligence (EQ) gives us awareness of our own and other people's feelings. It provides us with empathy, compassion, motivation and the ability to respond appropriately to pain or pleasures. Goleman has pointed out that EQ is a basic requirement for the effective use of IQ. If the areas of the brains with which we feel are damaged, we think less effectively (Goleman 1995).

D. Zohar and I. Marshall (2000) have applied the concept of spiritual intelligence (SQ) to the discussion concerning IQ and EQ. According to them, SQ helps us to assess the most meaningful course of action. With SQ, we address and solve problems of meaning and value. The authors claim that $S Q$ is the necessary foundation for the effective functioning of both IQ and EQ. SQ is our ultimate intelligence (Zohar \& Marshall 200o). The difference between EQ and SQ concerns the concrete situation in which they are used. Emotional intelligence allows us to judge what kind of situation we are in and then to behave appropriately within it. This is working within the boundaries of the situation, allowing the situation to guide us. Spiritual intelligence allows us to ask if we want to be in this particular situation in the first place. Would we rather change the situation and create a better one? This is working with the boundaries of our situation and allowing us to guide the situation. Similarly, the idea of spiritual intelligence has also been studied by Robert A. Emmons (1999: 176) as he describes spiritual intelligence as 'the adaptive use of spiritual information to facilitate everyday problem solving and goal attainment'.

Howard Gardner (1999: 54-8) has identified three domains of spiritual intelligence. First, he attributes the 'concern with cosmic or existential issues' 
to the sphere of spiritual intelligence. In fact, Gardner (1999: 60) has pondered whether it would be more appropriate to consider spiritual intelligence as a form of existential intelligence. Second, he emphasizes the 'spiritual as achievement of a state of being' which represents the psychological states and phenomenal experiences that are called spiritual. The third domain is 'spiritual as effect to others', a social aspect, which also coincides with the term charisma and is an important ingredient of conveying other people towards the fulfilment of the first two domains in their lives. Spiritual intelligence and its measurability has been a widely debated topic (see Emmons 2000; Gardner 2000; Mayer 2000) and the discussion continues.

\section{Spiritual sensitivity}

David Hay (1998) has identified three categories of spiritual sensitivity. Awareness sensing refers to an experience of a deeper level of consciousness when we choose to be aware by 'paying attention' to what is happening. This category coincides with Gardner's notion of the 'spiritual as achievement of a state of being. According to Hay (1998: 60) this kind of awareness refers to a reflexive process of being attentive towards one's attention or 'being aware of one's awareness'.

The second category of spiritual sensitivity is mystery sensing which is connected to our capacity to transcend everyday experience and to use our imagination. For instance, the beauty and wonder of sunrise and sunset includes the sense of mystery even after the scientific explanations are presented. The imagination is essential to religious activity through the metaphors, symbols, stories and liturgies which respond to the otherwise unrepresentable experience of the sacred. This category relates to both Gardner's understanding of spiritual intelligence as the 'achievement of a state of being' and the 'concern with cosmic or existential issues', while it emphasizes the mysterious nature of such experiences.

The third category of spiritual sensitivity is value sensing. This category emphasizes the importance of feelings as a measure of what we value. Among such things are the issues that touch our existential questions and meaning seeking (Hay 1998: 70-4). This category resembles Gardner's definition of spiritual intelligence as the 'concern with cosmic or existential issues'.

In the study by Kirsi Tirri, Petri Nokelainen and Martin Ubani (2006), a social dimension was added to Hay's three categories of spiritual sensitivity. The social aspect of spirituality has been suggested also by Gardner. The fourth sub-scale of spiritual sensitivity is called community sensing and is based on the work of J. Bradford (1995). Bradford has identified three types 
of spirituality. Human spirituality refers to the needs of care, love, security and responsibility we all desire. Devotional spirituality is built upon this human spirituality and it is expressed within a certain religious tradition, culture and language. The third type of spirituality is practical spirituality in which both the two other types of spiritualities merge. Practical spirituality is present in our everyday lives giving us direction and influencing our social responsibilities and concerns (Bradford 1995: 14). Bradford's definitions represent the social aspect in the domains of spiritual intelligence (Gardner 1999) and include the practical problem solving applications suggested by Zohar and Marshall (2000) and Robert Emmons (1999).

\section{Spirituality as expression of postsecular religiosity}

According to Hans-Georg Ziebertz and Ulrich Riegel (2008) postsecularity represents a discursive mode of religiousness. They build their definition on Habermas's (2001) philosophy in which postsecular religion meets three criteria: (1) acceptance of plurality, (2) communicating by reasoning, and (3) acknowledgement of fundamental rights. In the light of these criteria, spirituality can be examined as one form of postsecular religiosity (Tirri 2008).

According to recent empirical studies, an increasing number of people call themselves spiritual rather than religious (Heelas \& Woodhead 2005; Mikkola, Niemelä \& Petterson 2007). The British researchers Paul Heelas and Linda Woodhead argue that people do so because they are reluctant to commit themselves to hierarchies and would rather grow and develop as their own unique selves instead of going to churches and submitting themselves to their teaching (Heelas \& Woodhead 2005: 1-11). The Swedish researcher Ann Alden (2006) has analyzed the current religiosity as highly individualistic, experiential, non-authoritarian and non-dogmatic. In a recent Finnish study preadolescents perceived spirituality to be more connected to these qualities than the concept of religion (Ubani \& Tirri 2006). Today, religion cannot be poured over the people from outside in the form of habits or rituals. It is something to be experienced within the person. The traditional religion is seen to be bound to tradition and institutions, whereas spirituality is seen as contemplation of self and inner existentialism and concentration on experiences. Compared to the previous generations, the new generations try to more actively search for meaning and make sense of life themselves without ready answers given by the church. Spirituality now refers to what was earlier referred to as religion in the broadest and non-traditional sense (Mikkola $e t$ al. 2007: 111). 
Ninian Smart (2005: 12) uses the term 'religiosity above religions', when a person has a profound spiritual dimension without belonging to any movement or organization, or in a case when there is some transcendental influence in his/her life. Furthermore, religiosity can be called implicit religiosity when a person perceives communication with nature or relations to other people as spiritual. Moreover, esoteric movements, sects and New Age movements use the term spirituality in their vocabulary. The definition of spirituality must always be discussed in the contexts where it is used to get the right idea of its meaning.

The trend to describe oneself as spiritual rather than religious is present among Finnish young people. According to a recent telephone survey of 1,000 young adults 69 per cent consider themselves spiritual and 45 per cent consider themselves religious. Among those who have resigned from the church the corresponding figures are 73 and 21 per cent. Of those belonging to the church 46 percent considered themselves religious and 64 per cent spiritual (Mikkola et al. 2007: 112-14). The religious identities of young adults can be categorized in four groups. The majority of the young adults (37\%) identify themselves as religious and spiritual. They are more often female than male and have not lived in the metropolitan area all their lives and are likely to be more than 30 years old. These people typically have children and regard faith and religion as a somewhat or quite an important part of their lives. They most actively seek different parts of their world view from different sources and are most interested in buying spiritual literature. They tend to subscribe at some level to typical Christian beliefs and belong to the Evangelical Lutheran Church $(82 \%)$ or some other denomination. Furthermore, they actively or quite actively participate in private and public religious activities (Mikkola et al. 2007: 113).

Those who described themselves as religious-non-spiritual ( $8 \%)$ are the smallest group among young adults. They are most often found among those who have lived in the Helsinki metropolitan area only for a short time. They are also least interested in alternative religious movements and adhere to institutional religion. This is the group that agrees the most with Christian belief statements and are active in their religious practices. This group is most likely to agree that there is only one true religion in the world (Mikkola et al. 2007: 113).

The second largest group (34\%) among young adults consisted of those who viewed themselves as spiritual-non-religious. They are typically under 30 years and have lived in the Helsinki metropolitan area for more than 20 years. They typically disagree with Christian belief statements and are most 
in disagreement with a statement that there is only one true religion. Faith and religion do not have any major roles in their lives even though 74 per cent of them belong to the Evangelical Lutheran Church (Mikkola et al. 2007: 113-14).

The group $(21 \%)$ that was clearly least interested in all kinds of spiritual and religious matters were named non-spiritual/non-religious. A typical member of this group had lived in the Helsinki metropolitan area for more than 20 years. They typically do not believe in God or any kind of higher power and disagree with all kinds of belief statements. Even though they are religiously very passive, 77 per cent are still members of the Evangelical Lutheran Church or some other religious organization (Mikkola et al. 2007: 114).

These recent Finnish findings indicate that the differences between those identifying themselves as religious and/or spiritual adhere to the very same trend that can be seen in British and Swedish sociological studies. For those identifying themselves as only religious the role of institutional religiosity is strongest. Those who identify themselves as spiritual and religious are most open to alternative religious movements. Those who identify themselves as only spiritual adhere to the most relativistic world view. Mikkola et al. describe the current spirituality as an expression of postsecular religiosity in the following way:

Many of them felt a spiritual yearning, but this finds expression in new ways, where thinking combines a different religiosity of spirituality with science and rationality. This can be seen as the postsecularisation characteristic of the modern age. In postsecular thinking there is no denial of religion or spirituality, nor yet of science and rationality. In practice this is tolerance of many explanations and conflicting phenomena, where the religious solution is not adhered to nor is refuge sought in 'logical' solutions. Life is granted an element of mystery and myth, which cannot necessarily be converted into rationality. (Mikkola et al. 2007: 116.)

The above description of spirituality as an expression of postsecular religiosity meets the criteria by Habermas (2001). According to our review those people who identify themselves as spiritual accept plurality, are ready to communicate by reasoning, and acknowledge the fundamental rights of everybody. In the following chapter the spirituality of young adults is further explored as an example of postsecular religiosity. 


\section{The spirituality of young adults}

\section{Data and method}

The data for this study $(\mathrm{N}=500)$ was collected with a 20 -item instrument in 2004. The theoretical structure of the questionnaire has been analyzed earlier with a sample $(\mathrm{N}=496)$ that consists of the following three sub groups: (1) preadolescents $(\mathrm{n}=188),(2)$ adolescents $(\mathrm{n}=86)$ and $(3)$ adults $(\mathrm{n}=227)$. Results from this validation study are reported in our earlier work (Tirri et al. 2006). The spiritual sensitivity scale items were designed so that they would apply to people from different religious backgrounds and cultures. This allows us to use the instrument in a multicultural society and in cross-cultural studies. The statements described the issues and values that the respondent finds important for him/her. They were operationalized from the three categories of spiritual sensitivity identified by Hay (1998). Every category was presented in the questionnaire with five statements. For example, the category of awareness sensing was measured by the statement: item 5 'I try to listen to my body when I study and work'. An example item measuring mystery sensing was the statement: item 2 'I admire the beauty of nature, for example, the sunset'. The category of value sensing was measured, for example, with the statement: item 8 'I am searching for goodness in life. The categories of spiritual sensitivity by Hay do not explicitly express the aspects of a social dimension. Hence we added some statements measuring the social dimension of spirituality identified by Bradford and named the fourth sub scale Community sensing. These statements included items such as item 12 'I want to find a community where I can grow spiritually' (Table 1).

\section{Procedure}

The total population in Finland is $\mathbf{5 . 2}$ million. We chose an area in Helsinki called Kallio, with the largest population of young adults, to represent urban young adults in Finland. The total number of young adults living in Kallio was 12,564 at the time of this study. The percentage of people who leave the Evangelical Lutheran Church is largest in this age group among those who live in Kallio.

The sample was collected by means of phone interviews with 500 young adults (aged 20-39 year). Each respondent was personally invited to participate in the study. The study was part of a larger project researching young urban adults in the city of Helsinki. The participants were asked to use the Likert scale from 1 (totally disagree) to 5 (totally agree) to evaluate their attitude towards the statements measuring spiritual sensitivity. 


\section{Results}

Statistical analyses were conducted in two phases. First, we analyzed twenty items on the spiritual sensitivity scale and reduced the total number of items from 20 to 12 . Table 1 shows the descriptive statistics of the selected items on the spiritual sensitivity scale. The young adults have evaluated the item measuring mystery sensing 'I admire the beauty of nature, for example, the sunset' as the most important item measuring their spiritual sensitivity $(\mathrm{M}=4.3 ; \mathrm{SD}=0.8)$. The next highest-ranking items included an item measuring value sensing 'I rejoice in the beauty of life' $(\mathrm{M}=4.1 ; \mathrm{SD}=0.9)$ and an item measuring community sensing 'I want to advance peace with my own actions' $(M=4.0 ; S D=1.0)$. The least important items evaluated by young adults included two items measuring community sensing that dealt with de-

Table 1. The descriptive statistics of the spiritual sensitivity scale (Tirri 2008).

\begin{tabular}{|c|c|c|c|c|c|c|c|}
\hline & $\begin{array}{l}1 \text { Totally } \\
\text { disagree }\end{array}$ & 2 & 3 & 4 & $\begin{array}{r}5 \text { Totally } \\
\text { agree }\end{array}$ & M & SD \\
\hline $\begin{array}{l}\text { 1. In midst of busy everyday life I } \\
\text { find it important to contemplate. }\end{array}$ & 4 & 9 & 20 & 36 & 31 & 3.8 & 1.1 \\
\hline $\begin{array}{l}\text { 2. I admire the beauty of nature, for } \\
\text { example, the sunset. }\end{array}$ & 1 & 3 & 11 & 37 & 49 & 4.3 & 0.8 \\
\hline 3. I reflect on the meaning of life. & 3 & 16 & 31 & 30 & 20 & 3.5 & 1.1 \\
\hline $\begin{array}{l}\text { 4. I try to listen to my body when I } \\
\text { study and work. }\end{array}$ & 5 & 12 & 29 & 37 & 18 & 3.5 & 1.1 \\
\hline $\begin{array}{l}5 . \text { I want to advance peace with my } \\
\text { own actions. }\end{array}$ & 1 & 8 & 20 & 35 & 36 & 4.0 & 1.0 \\
\hline $\begin{array}{l}\text { 6. I want to help people who are in } \\
\text { need. }\end{array}$ & 0 & 6 & 24 & 46 & 25 & 3.9 & 0.8 \\
\hline $\begin{array}{l}\text { 7. Narratives and symbols are } \\
\text { important things for me in life. }\end{array}$ & 11 & 28 & 36 & 16 & 9 & 2.9 & 1.1 \\
\hline 8. I am searching for goodness in life. & 2 & 6 & 23 & 42 & 27 & 3.9 & 1.0 \\
\hline $\begin{array}{l}\text { 9. It is important for me to share a } \\
\text { quiet moment with others. }\end{array}$ & 42 & 35 & 14 & 6 & 2 & 1.9 & 1.0 \\
\hline $\begin{array}{l}\text { 10. There are many things in life to } \\
\text { wonder. }\end{array}$ & 1 & 4 & 16 & 41 & 38 & 4.1 & 0.9 \\
\hline 11. I rejoice the beauty of life. & 46 & 27 & 15 & 7 & 5 & 2.0 & 1.2 \\
\hline $\begin{array}{l}\text { 12. I want to find a community } \\
\text { where I can grow spiritually. }\end{array}$ & 46 & 27 & 15 & 7 & 5 & 2.0 & 1.2 \\
\hline
\end{tabular}

$\mathrm{N}=500$ (male $n=250$, female $n=250$ ). 
votional life. These items were the following: 'It is important for me to share a quiet moment with others' $(\mathrm{M}=1.9 ; \mathrm{SD}=1.0)$ and 'I want to find a community where I can grow spiritually' $(M=2.0 ; \mathrm{SD}=1.2)$. These items also had the biggest deviation between the respondents (see Table 1 ).

Second, we analyzed and compared the nature of spirituality between males and females and respondents who belong or do not belong to the church. Table 2 shows the most significant gender differences. In general, females evaluated themselves higher in every item than males, indicating that females are more spiritually sensitive than males. The same trend can be seen with all the other data sets collected with this instrument (Tirri et al. 2006). Furthermore, earlier empirical studies have shown that females are more religious than males (Tamminen 1996). Statistically significant differences between females and males were found with the following items: 'In midst of busy everyday life I find it important to contemplate', 'I admire the beauty of nature, for example, the sunset', 'I reflect on the meaning of life,' 'I try to listen to my body when I study and work', 'I want to help people who are in need',

Table 2. Gender differences in spiritual sensitivity (Mann-Whitney U-test) (Tirri 2008).

\begin{tabular}{|c|c|c|c|}
\hline The Item & Male & Female & $\mathbf{M}$ \\
\hline $\begin{array}{l}\text { 1. In the midst of busy everyday life I find it important } \\
\text { to contemplate. }\end{array}$ & 3.68 & 3.98 & $26776.0^{* *}$ \\
\hline $\begin{array}{l}\text { 2. I admire the beauty of nature, for example, the sun- } \\
\text { set. }\end{array}$ & 4.17 & 4.42 & $26432.0^{* *}$ \\
\hline 3. I reflect on the meaning of life. & 3.37 & 3.60 & $27494.0^{*}$ \\
\hline 4. I try to listen to my body when I study and work. & 3.37 & 3.66 & $27128.5^{* *}$ \\
\hline 5. I want to advance peace with my own actions. & 3.88 & 4.05 & 28470.0 \\
\hline 6. I want to help people who are in need. & 3.77 & 4.02 & $26009.0^{* *}$ \\
\hline $\begin{array}{l}\text { 7. Narratives and symbols are important things for me } \\
\text { in life. }\end{array}$ & 2.82 & 2.88 & 29888.5 \\
\hline 8. I am searching for goodness in life. & 3.77 & 3.94 & $28071.5^{*}$ \\
\hline $\begin{array}{l}\text { 9. It is important for me to share a quiet moment with } \\
\text { others. }\end{array}$ & 1.85 & 1.95 & 29095.0 \\
\hline 10. There are many things in life to wonder. & 3.85 & 4.02 & 28535.5 \\
\hline 11. I rejoice in the beauty of life. & 4.02 & 4.25 & $27394.0^{*}$ \\
\hline $\begin{array}{l}\text { 12. I want to find a community where I can grow spir- } \\
\text { itually. }\end{array}$ & 1.93 & 2.02 & 29333.5 \\
\hline
\end{tabular}

${ }^{*} \mathrm{p}<.05, * * \mathrm{p}<.01, * * * \mathrm{p}<.001 ; N=500$ (male $n=250$, female $n=250$ ). 
'I am searching for goodness in life', 'There are many things in life to wonder' and 'I rejoice in the beauty of life' (see Table 2).

We found three items with statistically significant differences between church members and non-members. The church members expressed more need for time for contemplation in the midst of busy everyday life and to share a quiet moment with others than the non-members (see Table 3). Furthermore, the young adults who belonged to the church expressed more need to find a community where they can grow spiritually than those young adults who did not belong to the church. In general, young adults did not differ very much from the other populations we have studied (preadolescents, students, peace keepers). Every group found spiritual values important in their lives. However, young adults differed from the other groups in their individual attitudes. They expressed less need to belong to a community and to share a quiet moment with others than the other populations we have studied (Tirri et al. 2006).

Table 3. Church membership and spiritual sensitivity (Mann-Whitney U-test) (Tirri 2008).

\begin{tabular}{|c|c|c|c|}
\hline \multirow{2}{*}{$\begin{array}{l}\text { The Item } \\
\text { 1. In the midst of busy everyday life I find it important } \\
\text { to contemplate. }\end{array}$} & \multicolumn{2}{|c|}{$\begin{array}{l}\text { Membership } \\
\text { Yes No }\end{array}$} & \multirow{2}{*}{$\begin{array}{r}M U \\
21021.50^{*}\end{array}$} \\
\hline & 3.90 & 3.64 & \\
\hline $\begin{array}{l}\text { 2. I admire the beauty of nature, for example, the sun- } \\
\text { set. }\end{array}$ & 4.29 & 4.30 & 23369.00 \\
\hline 3. I reflect on the meaning of life. & 3.49 & 3.47 & 23734.50 \\
\hline 4. I try to listen to my body when I study and work. & 3.56 & 3.44 & 22292.50 \\
\hline 5. I want to advance peace with my own actions. & 3.93 & 4.06 & 21682.50 \\
\hline 6. I want to help people who are in need. & 3.92 & 3.84 & 22946.50 \\
\hline $\begin{array}{l}\text { 7. Narratives and symbols are important things for me } \\
\text { in life. }\end{array}$ & 2.85 & 2.84 & 23618.50 \\
\hline 8. I am searching for goodness in life. & 3.89 & 3.76 & 22079.00 \\
\hline $\begin{array}{l}\text { 9. It is important for me to share a quiet moment with } \\
\text { others. }\end{array}$ & 2.02 & 1.58 & $17462.50^{* * *}$ \\
\hline 10. There are many things in life to wonder. & 3.92 & 3.84 & 22574.0 \\
\hline 11. I rejoice in the beauty of life. & 4.13 & 4.15 & 23095.50 \\
\hline $\begin{array}{l}\text { 12. I want to find a community where I can grow spir- } \\
\text { itually. }\end{array}$ & 2.08 & 1.67 & $18462.00^{* * *}$ \\
\hline
\end{tabular}




\section{Reflection on the results}

In this study, spirituality has been understood as a universal human capacity that can be found in every human being regardless of his/her religious or cultural backgrounds. Spirituality can also be seen as sensitivity with an emphasis on creativity and non-linear thinking. In education, spirituality means education for the whole person by acknowledging the importance of social and affective domains in addition to cognitive development. Spiritual sensitivity includes dimensions of awareness sensing, value sensing, mystery sensing and community sensing. In this study we have used a quantitative instrument measuring these four dimensions. According to the results, spiritual sensitivity is also important for young urban adults who are not actively religious. They need quiet moments in the midst of everyday life, mystical and aesthetic experiences to complement rational thinking, and they are searching for meaning and values in life. Young adults also want to act in ways which will advance the cause of peace. Females evaluated themselves as more spiritual than males in almost all the items measuring spiritual sensitivity (8/12). This finding is in accordance with earlier findings related to gender differences in religiosity. In general, young adults were quite individualistic in their preferences. However, those young adults who belonged to the church valued more community-oriented ways of practising spirituality. Those young adults who did not belong to the church valued mysticism, beauty and aesthetics. These dimensions of spirituality should be acknowledged more in church related activities with young adults as well. Spiritual development is a life-long process and it can be nurtured in the church and outside the church. A dialogue between the traditional religious practices and the postmodern ways of expressing spirituality could be a fruitful way to nourish the spiritual life of young urban adults. This can also be one approach for the church to reach young people who do not go to church.

\section{Concluding remarks and recommendations for future research}

In this article spirituality was examined within the educational framework. The concept of spirituality was contrasted to the concept of religion and the similarities and differences of their use in the professional literature were discussed. Spirituality was also explored in the psychological framework as a new possible intelligence type. The scientific debate of the existence of spiritual intelligence is still going strong. However, in the educational context, a 
majority of researchers and educators agree on the importance of developing the spiritual sensitivity of our youth. The sociological approach was emphasized in this chapter by seeing spirituality as an expression of postsecular religiosity. Recent European writings on the new generation and faith and values of young adults were used as theoretical frameworks to test this approach. New empirical research findings from Finnish studies were reported and discussed. According to both theoretical and empirical reflections on the values and religiosity of the new generation, the concept of spirituality has proved to be an adequate expression of postsecular religiosity.

Studying spirituality as expression of postsecular religiosity opens up new ways of studying religiosity. The empirical approaches and instruments in studies of religiosity have very much operationalized religiosity as dogmatic beliefs (such as a belief in a Christian God) or religious rituals (praying, attending services). We need new research instruments that are relevant for the new generation and acknowledge the current ways of expressing religiosity. These new ways include taking quiet moments in the midst of everyday life, mystical and aesthetic experiences to complement rational thinking and the search for meaning and values in life. This new generation also wants to act in ways that promote peace and human rights. Understanding spirituality as an expression of postsecular religiosity gives more room for young adults to participate in communicative actions concerning religion. This would promote discursive religiousness in the spirit of Habermas, in which a plurality of religious beliefs and practices are acknowledged and a dialogical and interreligious approach advocated.

\title{
References
}

\author{
Alden, Ann \\ 2006 Religion in Dialogue with Late Modern Society: a Constructive Contribution \\ to a Christian Spirituality Informed by Buddhist-Christian Encounters. Frank- \\ furt: Peter Lang.
}

\section{Bradford, J.}

1995 Caring for the Whole Child: a Holistic Approach to Spirituality. London: The children's society.

\section{Emmons, Robert}

1999 The Psychology of Ultimate Concerns. Motivation and Spirituality in Personality. New York: Guilford.

2000 Is spirituality an intelligence? Motivation, cognition, and the psychology of ultimate concern. International Journal for the Psychology of Religion 10 (3): 26. 


\section{Gardner, Howard}

1983 Frames of Mind. New York: Basic Books.

1999 Intelligence Reframed: Multiple Intelligences for the $21^{\text {st }}$ Century. New York: Basic Books.

2000 A case against spiritual intelligence. International Journal for the Psychology of Religion 10 (3): 27-34.

\section{Goleman, Daniel}

1995 Emotional Intelligence. New York: Bantam Books.

\section{Habermas, Jürgen}

2001 Glaube und Wissen. Rede zur verleihung des "Friedenspreises des deutschen Buchhandels", Paulkirche Frankfurt. In: Frankfurter Allgemeine Zeitung 15.10. 2001, p. 9.

\section{Hay, David}

1998 The Spirit of the Child. London: Fount.

\section{Heelas, Paul \& Linda Woodhead}

2005 The Spiritual Revolution: Why Religion is Giving Way to Spirituality. Oxford: Blackwell.

\section{James, William}

2003 The Varieties of Religious Experience. New York: Signet Classic. (Original work published 1902)

\section{Mayer, John}

2000 Spiritual intelligence or spiritual consciousness? International Journal for the Psychology of Religion 10 (3): 46-7.

\section{Mikkola, Teija, Kati Niemelä \& Juha Petterson}

2007 The Questioning Mind. Faith and Values of the New Generation. Tampere: Church Research Institute, Finland. (Publication 58)

\section{Pargament, Kenneth}

1999 The psychology of religion and spirituality? Yes and no. The International Jour-nal for the Psychology of Religion 9 (1): 3-16.

\section{Smart, Ninian}

2005 Uskontojen maailma. Keuruu: Otava.

\section{Stifoss-Hanssen, Hans}

1999 Religion and Spirituality: What a European Ear Hears. The International Journal for the Psychology of Religion 9 (1): 25-33.

\section{Tamminen, Kalevi}

1996 Gender differences in religiosity in children and adolescents. In: Leslie Francis, William Kay \& W. Campbell (eds), Research in Religious Education; pp. 163-88. Leominster: Gracewing.

\section{Tirri, Kirsi}

2008 Spirituality as an expression of postsecular religiosity. In: Hans-Georg Ziebertz \& Ulrich Riegel (eds), Europe as a Postsecular Society (EPOS). Reflections on Religion and Societal Cohesion; pp. 155-66. Muenster: Lit Publisher. 
Tirri, Kirsi, Petri Nokelainen \& Martin Ubani

2006 Conceptual definition and empirical validation of the spiritual sensitivity scale. Journal for Empirical Theology 19 (1): 37-62.

Ubani, Martin \& Kirsi Tirri

2006 How do Finnish preadolescents perceive religion and spirituality? International Journal on Childrens' Spirituality 11 (3): 357-70.

Ziebertz, Hans-Geog \& Ulrich Riegel

2008 Postsecular Europe-a concept questioned. In: Hans-Georg Ziebertz \& Ulrich Riegel (eds), Europe as a Postsecular Society (EPOS). Reflections on Religion and Societal Cohesion; pp. 9-41. Muenster: Lit Publisher.

Zohar, D. \& I. Marshall

2000 SQ - Spiritual Intelligence the Ultimate Intelligence. London: Bloomsbury. 